DOI: $10.17805 /$ ggz.2019.2.8

\title{
Феномен саморазвития человека: \\ кинезиология как тезаурус тела
}

\author{
Е. И. Ярославиева \\ Институт философии РАН
}

В статье рассматривается проблема саморазвития человека. Аутопоэзис - явление естественное, но требует постоянных усилий, осознанной работы, иели. Предметность кинезиологии - активное движение. Речь идет о намеренной мышечной активности, когда тело высказывается, как и язык, помогая человеку выразить свое состояние, продвинуться к иели. И чтобы речь была красивой и правильной, важно поддерживать себя в форме, иметь свой набор упражнений, которые помогают быть здоровым, активным и сбалансированным, достигать результатов в решении проблем.

Ключевые слова: саморазвитие; движение; тело; здоровье; помощь; кинезиология; тезаурус; тезаурус тела

\section{The Phenomenon of Human Self-development: Kinesiology as a Body Thesaurus}

\author{
E. I. Yaroslavtseva
}

Institute of Philosophy, Russian Academy of Sciences

The article examines the issue of self-development of a person. Autopoiesis is a natural phenomenon, but it requires constant efforts, conscious work, and a goal. The objective side of kinesiology is an active movement. This is deliberate muscular activity, when the body expresses itself, as does the language, helping the person to express his/her condition and to move towards the goal. And in order to have a beautiful and correct speech, it is important to keep fit and to have one's own set of exercises that help you to be healthy, active and balanced as well as to achieve results in solving problems.

Keywords: self-development; movement; body; health; help; kinesiology; thesaurus; body thesaurus

\section{ВВЕДЕНИЕ}

Современное общество несет в себе множество проблем, но также содержит и решения, которые могут для одних иметь большое значение, а для 
других остаются малоэффективны. Способы решения фактически подобны словам, которые мы все используем в общении, но говорим именно так, как получается. За решением мы можем обратиться не к кому-то другому, а к себе, поискав потенциал именно в своих незадействованных ресурсах. Человек вырабатывает навыки самоорганизации, когда возникающие проблемы значительно выше по сложности, чем встречаются обычно. Он чувствует необходимость осознанной аутокоммуникации, обращения к знаниям по использованию своих психофизиологических ресурсов для саморегуляции, предварительной подготовки к нагрузкам. Многие традиционно используют тактику «не обращать внимания», но все чаще встречаются те, кто готов быть в диалоге с собой, сотрудничать со своей природой, умеет поддерживать жизнеустойчивость.

\section{ФИЛОГЕНЕЗ: КАК ТЕЛО ВЕЩАЕТ}

В конце XX в. вопросы, связанные со стремлением человека познать свое собственное тело, активно покидали зону сакральности: выходило много работ не только для профессионального сообщества, но и для широкой публики. Было ясно, что массовому читателю знакомство с тематикой тела было интересно и важно, поскольку в большинстве читатели были образованные. Они были готовы знакомиться с разными культурными и научными теориями и позициями. Проблемы, связанные с системами самоуправления организма, были, безусловно, самыми интересными, хотя пальма первенства была у литературы по проблемам сексуальной жизни, общения полов. Но важно зафиксировать разнообразие поиска ${ }^{1}$.

Среди многих направлений заявила о себе кинезиология - практикопознавательный подход на основе телесно-ориентированных эмоциональнопсихологических методик. Активно рассматривались вопросы психофизиологической тематики. Кинезиология (лат. kinesis и logos) - наука о движении ${ }^{2}$, которая позиционирует себя как система знаний, построенная на изучении связи рефлекторных ответов и в целом движения мышц с эмоциональнопсихологическим состоянием человека. В отечественной науке в начале

\footnotetext{
1 Назовем некоторых авторов, которых, конечно же, значительно больше: А. Азимов, Ф. Александер, Р. Аткинс, Г. Бейтсон, И. М. Быховская, К. Вульф, А. Ф. Ермошин, А. Лоуэн, В. Н. Никитин, Н. А. Носов, В. Райх, С. В. Савельев, И. В. Смирнов, Г. Стоукс, А. Н. Стрельникова, А. Ш. Тхостов, Д. Уайтсайд, П. А. Флоренский, М. Фуко, Я. В. Чеснов, И. А. Шамов, В. Б. Швырков, К. Г. Юнг, З. Фрейд. Необходимо также отметить развитие системных исследований по биоэтике, начатый в Институте человека РАН (директор - акад. И. Т. Фролов) в 1992 г. Б. Г. Юдиным, П. Д. Тищенко и другими специалистами междисциплинарного знания.

2 Понятие «кинезиология» находится в стадии формирования. См.: Кинезиология, 2018: Электронной ресурс.
} 
XX в. серьезно разрабатывалась концепция «биомеханики», в основе которой лежали разработки по физиологии труда крупнейшего советского ученого, психофизиолога и педагога Н. А. Бернштейна 3 .

Исследуя формирование структуры человеческой деятельности, он выявил уровни сложности, которые определяли характер реакции биосистемы на окружающий мир, систему обратной связи, своеобразного диалога. Он выявил, что деятельность человека можно разделить на пять уровней движения. Это уровни $A, B, C, D, E$, которые проявляются по мере физиологического созревания человека, расширения возможностей его мозга. При этом новые системы сигналов в организме возникали буквально в непосредственной связи с тем, как формировались уровни, слои нервных волокон мозга (мозг имеет разную толщину коры). Первые три уровня $(A, B, C)$ можно наблюдать у сложных животных и у человека, а последние $(D, E)$ - в основном у человека. Каждый новый уровень движения надстраивается над предыдущим, создавая более сложную и в то же время более открытую систему связей, диалога организма с внешним миром. Он становится новым вариантом использования тех действий, которое делает человек на предыдущем уровне (Бернштейн, 2008).

Приведем еще одно утверждение из более позднего труда исследователей конца ХХ века У. Матураны и Ф. Варелы: «Что бы и в какой бы области мы ни делали - конкретное (ходьба) или абстрактное (философское размышление), - это действие захватывает целиком все наше тело, ибо осуществляется через нашу структурную динамику и через наши структурные взаимодействия. Все, что мы делаем, - это структурный танец в хореографии сосуществования» (Матурана, Варела, 2001: 218).

Фактически можно говорить, что биологическая система имеет свой внутренний язык и как целостность получает через обратную связь всю полноту информации, которая ей доступна в соответствии со своим филогенетическим уровнем, воспринимает то, что ей принципиально важно. Более поздние, сложно согласованные структуры уровней $\boldsymbol{D} u \boldsymbol{E}$ могут проявлять себя через собственно человеческие потребности. Можно заметить, что последний из выявленных уровень $(\boldsymbol{E})$, соотносимый с возрастом 5-7 лет, при специализации левого полушария формирует у человека способность к конструированию, а значит, несет в себе более высокий уровень свободы.

\footnotetext{
${ }^{3}$ Советский психофизиолог Н. А. Бернштейн (1896-1966) - основоположник исследований по физиологии активности, сформулировал понятие обратной связи в физиологии. С 1922 г. возглавлял Государственный институт охраны труда. Его основным фундаментальным исследованием является научный труд «О построении движений», удостоенный в 1947 г. Сталинской премии (Бернштейн, 1947; см. также: Бернштейн, 1966). Имеет большое научное наследие: Бернштейн ..., б/д: Электронный ресурс.
} 
Развивая сформировавшийся потенциал, человек выходит фактически на этап самостоятельного творческого созидания, управляемый не только биологической необходимостью, но, в первую очередь, актуальными потребностями в актуальной ситуации. Человек может быстро откликаться на разные события, что позволяет ему в резко изменяющейся ситуации повысить свою устойчивость и даже сохранить жизнь. В этом случае, как можно заметить, человек уже с детства адаптируется к состоянию свободы и может проявлять творческие способности, развивать их в самых разных направлениях, поскольку он одинаково равно не специализирован в своей деятельности. Наряду со свободой, позволяющей человеку конструировать свою действительность, задавать события своей жизни, чего нет у животных, важнейшей составляющей становится осторожность, предусмотрительность, а в конечном счете ответственность, поскольку никто, кроме него самого, не может сохранить его жизнь. После ряда рискованных событий беспечный ребенок, как правило, превращается в разумного индивида и научается ценить свою жизнь. С этого момента пара этических понятий «свобода - ответственность» создает модуль его поведения, который гарантирует высокий уровень выживаемости в природной стихии.

Индивид, накапливая в онтогенезе новый ресурс, старается реализовать свой потенциал, что определяет его интерес к знаниям о своей телесности в повседневной практике телесное и духовное не были антагонистами. Иногда это просто опыт восстановления здоровья, но кроме этого для каждого было важно иметь связь с более глубокими защищающими силами. Самыми близкими как раз являются собственные потенциальные возможности, которые необходимо разбудить и использовать. Человек в этом стремлении пытается закрепить имеющиеся возможности и освоить новые уровни свободы. Он, по существу, старается создать интуитивную или осознаваемую аутокоммуникацию, что позволило бы выработать навыки баланса организма как целостности, при необходимости быстро решая задачи самоорганизации.

Стоит заметить, что значительное количество исследований, рассматривающих психосоматические, телесноориентированные подходы к исследованию телесности человека, не используют представление о коммуникативных аспектах развития биосистемы, не обращаются к понятию процесса, без которого немыслимо представить возможность самоорганизации человека, саморегуляции, поддержания баланса. Несмотря на всю сложность поставленных проблем, изучение механизмов функционирования организма, существование собственно телесности описано достаточно механистически, максимально дифференцированно. И это естественно, поскольку тело рассматривается как объект, и чаще всего как объект патологоанатома, где все функции развития уже прекратились. Бытие биосистемы уже закончилось, ауто- 
коммуникация завершилась. Произошедшее остается только в памяти живущих и описывается посредством их собственного восприятия, которое имеет культурные формы, социальные традиции. Многие мыслят свое существование за пределами жизни как духовное перенесение в другие миры, но значительное количество живущих людей считает, что это гипотеза и надо успеть сделать, что возможно, еще при жизни.

Человек в своей объектной форме рассматривается со стороны, с позиции наблюдателя, что соответствует классической парадигме. Смягчает ситуацию психофизиологический дискурс, когда при описании тела используются метафорические выражения «язык тела», «грамматика тела», а также «семиотика тела», где тело вбирает в себя все разнообразие значений, оставаясь при этом лишь целостным образом, недифференцированным, фактически не гибким, неподвижным. Рассматриваются, как правило, внешние, уже устоявшиеся феномены его проявления, а также передается многообразный опыт обращения со своим телом. Человек, желающий быть здоровым, успешным, красивым и счастливым, должен выполнять определенные правила, сохраняя и умножая свои ресурсы. Возможно, именно это было основой всплеска интереса к самому себе, когда рухнула одна социальная система и открылась перспектива создания новой. Как всегда, неофитам пообещали обновления и открытия в себе новых творческих сил, и они устремились за новыми знаниями.

Обилие литературы, как хлынувшее в массы, так и оставшееся в сакральном пространстве, показывает общекультурные тенденции, социальную жизнь. Предлагаются осмысление тела, определенные интерпретации, знаковые трансформации, но это значит, что динамика реализуется только через активность автора, наращивающего смысловую составляющую. Психологические технологии работы с телом, как классические, так и современные, очень сильно трансформируются от методики к методике, демонстрируя гибкость мысли и практики автора работы. А это значит, что динамичность движения проходит исключительно за счет интерпретаций автора, но никак не того, кому эти рекомендации даются. Но, даже если сам автор может быть причастен к описываемому опыту, может проводить психологические исследования и измерения и даже писать для другого человека, он не становится идентичным тому другому, к которому обращается. Это онтологическая граница и преодолеть ее невозможно.

Вопрос, конечно, не в том, правильные эти знания или нет - сколько бы их ни было, они проявляют многообразие индивидуального опыта, что и является самостоятельной культурной ценностью. А конкретный человек может обратиться к этой копилке, а по-современному — big data, и черпать в той мере, в которой найдет нужным. Но в первую очередь ему нужны точки 
опоры, которые он может найти в самом себе, чтобы развиваться, опираясь на них и достигая той успешности в социальном мире или удовлетворенности своим внутренним миром, о которых сообщают многочисленные авторы. Важно понять, что в этом тематическом пространстве мы имеем дело с принципиально разным культурным опытом: и в индивидуальном, и в социальном формируются разные языки и системы знания, различные подходы к описанию телесности.

В социуме рассмотрение телесности часто связано с профессиональной деятельностью, медицинской и психологической практикой, где индивид воспринимается как объект воздействия, эксперимента или социальной организации, порождая определенный язык, тезаурус (Валитова, 2007; Осокина, 2012, 2015). Индивид для социума - это ресурс, общество существует именно силой человека, взаимодействием людей. Но и человек также начинает осознавать свою индивидуальность, понимать, что он также сам себе хозяин - именно он может более эффективно определить, что ему необходимо делать, поскольку способен чувствовать свой потенциал. Он не только имеет право распоряжаться собой, но и ответственен за свое развитие. Более того, он заинтересован в том, чтобы выжить самому и по мере сил и возможностей помочь в этом другим, не заменяя их. По существу, человеку нужно помочь в коммуникации с собой, в развитии аутокоммуникации, через которую он создает внутреннюю устойчивость и затем может успешно строить взаимоотношения с внешним миром. В этой повседневнеой практике он учится достигать баланса, фактически опираться на свое состояние здоровья и понимание его. Индивидуальная активность в этом направлении зачастую способна более продуктивно решать задачи общесоциального характера, поскольку человек никогда не останавливается в реализации собственного интереса и на своем уровне значимости прорабатывает социальные проблемы.

\section{ПРОБЛЕМА ПЕРЕХОДА}

Однако активность в самоорганизации открывает перед человеком достаточно большие сложности. Обращаясь к себе, он строит новые коммуникации, но не имеет достаточно развитой системы описания своих состояний, внутренних трансформаций и языка в целом. Он, безусловно, пользуется тем, что существует в традициях, культуре, понимает себя через этот тезаурус как своеобразный интерфейс. Но если учесть, что динамика современного индивида достаточно высока, то происходит его привязка к прошлому, но отсутствует его понятийная индивидуальная ориентация в будущее, что расслаивает его целостность. Знакомство с обилием литературы, языковых выразительных средств по теме телесности человека не только вводит его в мир культурной истории, но и ставит его перед выбором - чего придерживаться? 
Современная ситуация с Интернетом как гипертекстом многократно усложняет эту задачу. Издатели литературы non-fiction ${ }^{4}$ (наиболее удачный перевод этого словосочетания - «невымысел», а близкий нашему пониманию - документалистика) рекомендуют обилие гастрономических рецептов здоровой жизни, множество путешествий, видов отдыха, праздников, а также досуга со спортивно-оздоровительным уклоном.

На сегодняшний день это самый читаемый жанр, приносящий издателям уверенность в будущем, который позволяет читателям черпать много интересной информации, в том числе оздоровительного, психологического характера. В совокупности электронные и бумажные носители информации предлагают широкий выбор приемов и упражнений, которые в массе своей непроверяемы. Не только потому, что они не проходят никакой экспертизы, а сами являются литературой от «лучших», но и потому, что невозможно познакомиться со всем потоком публикаций, поскольку на каком-то этапе «потребления информации» читатель начинает просто «выгорать». Этот поток обращен не просто к идеям и представлениям человека, а к вкусам, запахам, физическому чувствованию, аудиовизуальному восприятию и прочим видам сенсорного эмоционального переживания, стремящегося вызвать удовлетворение. Кажется, что это книжный Клондайк на шикарной бумаге от цифровой полиграфии, которую держать хочется только в перчатках, осознавая при этом, что находишься не в своем ценовом сегменте! Усталость читателя от свободы издателя и писателя вполне закономерна.

Столь интенсивное обновление издательской, книжной среды, безусловно, сдвигает рамки прежнего мироощущения, и на каком-то этапе может произойти «тезаурусный щелчок», на который обратили внимание исследователи современных процессов коммуникации (Луков В., Луков Вл., 2014: 28). Этот «щелчок» порождает опорный набор понятий, словарь для ориентации в мире (Луков В., Луков Вл., 2004). Когда это произойдет у каждого, предсказать невозможно. Информационное пространство пока наращивает только хаос, а таким «тезаурусным щелчком», запускающим аттрактор развития, может оказаться, например, система «лайков» в сети, на которые чутко реагирует молодежь, подростки. Подобная ситуация широко распространена в системе рейтингов, критерии которых высоко изменчивы и не только в сети, но вводятся и в систему организованного знания, науку, которая всегда считалась надежным инструментом описания мира.

По существу, индивид живет в гарантированно усложняющейся ситуации, при высоких нагрузках, и ему необходим опыт создания способов само-

\footnotetext{
${ }^{4}$ Одно из наиболее модных современных направлений в издательском деле, востребованное читателями. См., например: Tgorlopeev, 2017: Электронный ресурс.
} 
поддержки, своеобразного психофизиологического иммунитета, который всегда исключительно индивидуален и настроен «на вырост», подобран природой для гибкого балансирования особи. В критических ситуациях необходимо искать точку опоры внутри, а не вне системы, и это - творческое, нестандартное применение накопленного опыта. Пока не будет решена задача самоорганизации индивида, обращенная не только к теоретическим концепциям, но и к практике, с телом человека будут происходить многочисленные события, связанные с насилием со стороны внешних сил, с вольными или невольными манипуляциями. Социум становится пространством, в котором многие склонны распоряжаться ресурсами населения ради своих интересов.

При подобной целеустремленности всякое новое изобретение будет сначала играть роль оружия и лишь потом превращаться в продуктивно работающий для всех инструмент, орудие (Ярославцева, 2016). Фактически многие открытия происходят именно на этом этапе, когда социально энергичный индивид ищет способы самоутверждения и идет путем подавления других, опираясь не на диалог, а на манипуляции. Особенно страдают от этого конкретные индивиды, которые не могут противостоять такому давлению, выйти из-под влияния. Глобализирующееся общество создает новый формат коммуникаций: сети взаимодействия, которые раньше, конечно же, существовали, становятся цифровыми и вовлекают в тесное общение людей, которые раньше бы и не знали друг друга. Виртуальные сетевые коммуникации вдохновили возможностью мгновенного перемещения в новые пространства, но одновременно принесли и немало рисков, о которых мало кто мог предположить. Это пространство весьма мощных механизмов управления. Возникает система умного города, где каждый предмет, имея свой электронный адрес, может быть дистанционно управляем. Не сложно предположить, что таким объектом может быть индивид, который по причине слабого здоровья может в принципе иметь внутри себя несколько цифровых датчиков со своими адресами 5 . Облегчение дистанционного доступа, как многие сегодня уже понимают, не снимает проблемы, а переводит их на другой уровень сложности. Уже сформировалась эта проблемная область - как в этих условиях индивид может оберегать свою автономность и решать задачи самоорганизации, следуя природной логике аутопоэзиса.

Цифровое пространство фактически может быть эффективным для осуществления коммуникаций в его диалоговых формах, что ранее было

\footnotetext{
${ }^{5}$ C 2010 г. 9 апреля отмечается Международный день Интернета вещей, который показывает неслучайную тенденцию, а закономерный процесс развития системы цифровых сетевых коммуникаций в обществе, которые расширяют сеть не только за счет вовлечения субъектов, но и объектов, как природных (например, деревья), так и искусственных (например, бытовые приборы).
} 
весьма затруднительно, но теперь вполне реально. Но при взаимоотношениях часто происходят манипуляции и провокации, осуществляется прямая дезинформация, т. е. в социуме используется соответствующий тезаурус без признания равных прав партнера, создается необходимость перехода к накоплению каждым человеком опыта диалога. Может показаться странным, но потенциал его расширения лежит в области отношения человека к самому себе, не только как к природному феномену, несущему в себе филогенетическую память предков, но и осознающему себя как ценность культуры, человеческого развития. Конечно, подобное отношение и самопонимание совсем не характерно для многих, но это же и показывает, что внешние проблемы в определенной мере отражают внутренний статус человека, неспособного защитить самого себя, предотвратить негативные процессы, подавляющие жизнь.

Человек углубляется в знание глубинных процессов, где основным проводником в мир тонких манипуляций служат цифровые инструменты, являющие человеку визуальные, аудиальные, стереоскопические объекты внутреннего мира человека, показывающего процессы протекания жизни, в которую можно вмешаться, встроив свою волю, осуществляя преобразования даже на уровне генотипа. Хрупкие механизмы настройки природы не могут на это не реагировать, а значит, следует достаточно точно строить прогнозы рисков такого взаимодействия, фундаментальной коммуникации с природой. Необходим язык описания таких отношений, представление об обратной связи между глобальными природными и не менее глобальными социальными феноменами, оснащенными новыми технологиями. Это также можно рассматривать как аутопоэтический процесс такого субъекта как социум, однако в современной цифровой среде он подвергся серьезному изменению, его потенциал вырос. В связи с этим требуется пересмотреть прежние, даже не очень четкие представления по этому вопросу, в частности, статус человека как индивидуального субъекта.

Собственно, проблема аутопоэзиса и, соответственно, баланса в сложных системах при любых трансформациях становится самой острой. Здесь приходится иметь дело не только с усложняющимся социумом, но и с развитием функциональных возможностей индивида, которые в свою очередь влияют и на усложнение социума. По мнению Г. М. Маклюэна, речь идет о таком феномене, как расширение человека через создание различных технологий, усиливающих функции человека и количественно умножающих материальное богатство общества, что последовательно ведет к «ампутации» этих способностей и зависит от техники (Маклюэн, 2003). Подобным образом человек не просто влияет на культуру, но через технологические достижения и изобретения он как бы «отбрасывает» от себя собственные способности, ин- 
дивидуальный потенциал. В этом рассуждении можно увидеть негативный контекст расширения, своеобразную потерю ресурса, истощение человека.

Если же сосредоточиться на более глубоком гуманитарном, а не технологическом смысле процесса расширения, то можно заметить, что происходит создание структурных точек опоры, подготовка новых горизонтов развития. Имеет место не отторжение человека, а более продуктивный процесс дистанцирование, которое не разрывает связь с предшествующими формами существования, а «растягивает» их на дальние расстояния, применяет в других условиях, иных пространствах. И это мы видим по системе коммуникаций в социальных сетях, где человек не теряет связи, если успевает освоить системы нового, виртуального общения.

В данном случае человек не растворяется в поле подобных сетевых коммуникаций, но задает ритмы развития, согласованные с ним. И чем более человеку удается удержаться в природном пространстве, тем более самостоятельным становится его существование, задающее свой темп, режим развития. С какого-то момента, что бы ни происходило с природой, человек может рассматриваться уже как источник формирования коммуникаций, порождающий не только свой, но и социальный потенциал развития. В принципе, эта способность в человеке как социальном существе была всегда, но она не обнаруживалась столь явно. Лишь при интенсивной оцифровке функциональных возможностей человека стало понятно, что потенциал визуальных и аудиальных функций природного существа настолько высок, что способен освоить гипер- и микромасштабирование в восприятии природы. Он может различать параметры измерений и соотносить исследуемые объекты, понимая их как единую социально-природную целостность.

В культуре цифровых, а в дальнейшем, возможно, и квантовых технологий человек способен стать принципиально самостоятельным существом, обладающим способностью к автономному самосозиданию. Способность к ааутопоэзису в него не вносится, она существует с рождения как данность природы. С детства у него возникает стремление совершенствовать и упорядочивать то, что рождено природой, и каждый раз эта задача должна решаться самостоятельно, с опорой на свои внутренние ресурсы. Взрослеющий индивид начинает искать более крупные задачи, готовиться к достижению целей, в которых проявляется его зрелость. Собственно говоря, здесь получает воплощение этическая максима - спрашивать надо только с самого себя.

Элементы аутопоэтического развития, соотношения с самим собой, рождающие социальное самосознание не только человека, но и поколения, формируются не просто. Они соответствуют бурному психофизиологическому процессу созревания, а потому достаточно противоречивы - у многих периоды ясности в этом вопросе сменяются периодами полного недоверия к 
себе. В современных цифровых вселенных, при виртуальном жизненном опыте рефлексия как самоотношение может формироваться достаточно поздно, поскольку человек воспринимает виртуальную среду как игровую, что соответствует детскому возрасту. Иными словами, человек может долго быть инфантильным, считать, что есть запас заложенных возможностей, откладывать принятие решений, многое не принимать во внимание.

\section{ДИАЛОГ ЧЕЛОВЕКА С ПРИРОДОЙ В СЕБЕ}

Но при этом важно заметить, что данный период часто оказывается связанным с необходимостью решать весьма противоречивую задачу: освоить предоставленную свободу и сфокусироваться и собраться. Оказываясь перед выбором, всякое живое существо вырабатывает определенную тактику, сопряженную с уровнем филогенетической зрелости особи, как животного, так и человека. В определенных условиях может возникнуть психологический эффект взаимоисключающего опыта, ультрапарадоксальное состояние, поведение в ситуации «сшибки», которые как устойчивый феномен были отмечены в середине ХХ в. российским ученым Б. Ф. Поршневым (Поршнев, 2007: 199). Подобные проблемы у представителей животного мира могут привести к смерти, но человек имеет более гибкую нервную систему, он в принципе способен компенсировать торможение и выйти к новым горизонтам, хотя для этого может потребоваться очень много ресурсов. Но это говорит о том, что глубинные проблемы человеку приходится преодолевать, сосредотачиваясь на самом себе, не рассчитывая, что кто-то может прийти и изменить все в лучшую сторону. Лучшее он определяет для себя сам.

В принципе, в этом состоит механизм аутопоэзиса, постоянной сложной внутренней переклички. И человек может понимать эти сигналы, осознавать подсказки, иметь свой словарь значимых слов, понятий и образов (тезаурус), чтобы поддерживать самого себя в сложных ситуациях. Находясь на сложном уровне биосоциального развития, человек, как и всякий организм, находится в системе интерактивной коммуникации, включен во взаимодействие со средой и условиями существования. Тело фактически всегда подает определенные сигналы, которые в зависимости от обстоятельств можно игнорировать или воспринимать.

Подобный диалог нередко имеет стихийную форму, которая очень ярко выражена у ребенка: он может потянуться, почесаться, крутиться, баловаться, бегать, «выскочить» из условностей жизни. Когда человек взрослеет, то ему уже приходится следить за собой, самоорганизовываться, чтобы быть более понятным для других. Но при этом его поведение стандартизируется под требования, условия учебной или профессиональной деятельности. Именно в этих случаях возникает необходимость заняться специальной «ско- 
рой помощью» самому себе, чтобы поддерживать собственное свободное развитие. Иными словами, человеку нужно организовать свободу не вовне, а, в некотором смысле, внутри себя. Чтобы быть максимально подвижным и в то же время устойчивым, важно создать для всей мышечной системы способность балансирования, перераспределения нагрузок ${ }^{6}$. В конечном счете внутренняя гибкость организма обеспечивает и внешнюю способность балансирования, взаимодействия с миром, что является не фигурой речи, а конкретной способностью пластичного реагирования системы для удержания равновесия, которое обеспечивает орган, расположенный в ухе человека, реагирующий на гравитационное поле Земли ${ }^{7}$. Другими словами, занимаясь собой, своим здоровьем и устойчивостью, человек не восстанавливает потерянное, а компенсирует перегрузки, помогая своим природным потенциям сохраняться и, раскрываясь, адекватно решать задачи развития.

Сегодня, в конце второго десятилетия нового тысячелетия, в мире, где в медицине реальностью стали цифровые технологии и искусственные имплантаты уже никого не удивляют, вполне понятно, что каждый человек должен иметь достаточно полное представление о своем теле, его функциях, особенностях развития, поскольку несет ответственность за свое собственное состояние здоровья. Он сегодня должен иметь достаточно полный тезаурус / представление о своих возможностях. Это особенно важно в тех случаях, когда он, не являясь компетентным, по сравнению с врачом, человеком, должен быть готов всегда иметь возможность в соответствии с биоэтическим принципом «информированного согласия пациента» ${ }^{8}$ выразить или отклонить свое согласие на то или иное медицинское вмешательство. Со многими пациентами не только достигают согласия, но и проводят осознанную со стороны пациента подготовку к сложным операциям. Владение основными понятиями собственного тезауруса становится уже культурной нормой. Болеющему че-

\footnotetext{
${ }^{6}$ Классиком в помощи восстановления жизненных сил человека считается американский психотерапевт Александр Лоуэн (Alexander Lowen, 1910-2008), книги которого знает практически каждый человек. Для понимания принципов биомеханики надо знать оси и плоскости тела человека (см., например: Касаткин, Ачкасов, Добровольский, 2016: 14-17). ${ }^{7}$ Орган гравитации и равновесия является одним из самых незаметных для человека, неявных парных органов в составе уха с правой и левой стороны. Это мощная форма природного, фактически эффективный биологический инструмент космического управления жизнедеятельностью индивида.

${ }^{8}$ Принцип биоэтики, который был введен в практику медицинских работников по модели работы биоэтических комитетов, которые активно работали в Европе. Стоит заметить, что трансформации в отношениях врача и пациента как коммуникативной пары совпало с периодом разработки системы обязательного медицинского страхования (ОМС), новых принципов управления здоровьем в России, утвержденных в 1991 г. Закон об ОМС, защищая пациента, декларировал свободный выбор врача, а также и принцип информированного согласия, который еще достаточно долго не вводился в действие.
} 
ловеку приходится обучаться «на ходу», проходя просвещение непосредственно с лечащими врачами, если до этого не приходилось искать ответы в сетях Интернета. При этом для многих уже вполне естественно осознанно стремиться к здоровью, заниматься правильным, оптимальном питанием, заботиться о нормальном весе, избегать рисков для здоровья, стараясь совсем не приближаться к границам, где возможно возникновение заболевания. В 90-х годах XX века в вузах была введена даже такая дисциплина - валеология, по которой готовили исследователей и специалистов, но при отсутствии необходимых корректно разработанных учебных программ, она не получила значительного развития 9 .

При широкой доступности информации и критическом к ней отношении каждый, в конечном счете, сам набирает комплекс знаний, стремясь подкрепить свой мотив быть здоровым практическими действиями, пригодными для повседневной жизни. Можно сказать, что у человека появляется своеобразный тезаурус - комплекс упражнений, приемов, принципов, а также моделей поведения, выраженных в речевых формах. Если составить подобный междисциплинарный тезаурус, то можно обнаружить, что у каждого найдутся свои наиболее эффективные приемы, которые помогают человеку мобилизоваться, организоваться для выполнения поставленной задачи.

9 Существенный вклад в развитие проблемы внесли представители военной медицины, занимающиеся медицинским обеспечением лиц, которые работают в условиях экстремальных воздействий. В начале 1970-х гг. И. А. Сапов совместно с сотрудниками (Г. Л. Апанасенко, Ю. М. Бобров, А. С. Солодков, В. С. Щёголев и др.) сформулировал учение о «физиологическом обеспечении» походов подводных лодок. Впервые была сделана попытка «управления» функциями организма, которые отвечают за профессиональную работоспособность подводников. В космонавтике было сформулировано понятие «донозологическая диагностика» (Баевский, Берсенева, 2001; Баевский, Максимов, Берсенева, 2001), которое с успехом использовалось и в гражданском здравоохранении (Казначеев, Михайлова, 1981; Казначеев, 1997ab). Основоположником науки о здоровье в современном ее понимании считается выпускник Военно-медицинской академии им. С. М. Кирова И. И. Брехман, вернувшийся к методологическим основам охраны здоровья практически здоровых людей. Исследуя роль адаптагенов и сформировав новое научное направление - фармакосанацию («лекарства для здоровых»), он пришел к мысли о необходимости изменить всю стратегию здравоохранения путем изучения этиологии и механизмов здоровья индивида. Назвав обоснованное им научное направление «валеологией» (от лат. valeo - «здравствовать», «быть здоровым»), он в 1987 г. выпустил первую монографию, а в 1990 г. вышло второе, дополненное и переработанное издание этой книги (см.: Брехман, 1990). Важно заметить, что валеология - отечественный научный подход, на основе которого уже в новом тысячелетии проводились конференции, выпускалась литература (см.: Бахтин, 2015). Специалистами, работавшими в междисциплинарной сфере медицины и философии (Л. Г. Татарникова и ее ученики), развивалась педагогическая валеология (Татарникова, Захаревич, Калинина, 1997; Татарникова, 2010). В связи с кризисом валеология значительно снизила темпы развития. Так, научно-практический журнал «Валеология», который издавался с 1996 г., в 2018 г. прекратил свое существование. См.: http://journal.valeo.sfedu.ru. 
Активно действующий человек всегда заинтересован помогать себе и готовиться к решению трудных задач, чувствовать свою эффективность. Он может не только иметь хорошие показатели по принятым нормам, когда точно знает свое соответствие стандартам, но и нередко стремится поддерживать хорошее настроение как у себя, так и у других. Человек хорошо себя чувствует, когда вокруг него все благоприятно, когда он согласован с миром, людьми, которые его окружают. Тогда кажется, что все его оберегает и ему по силам все мечты, которые он стремится воплотить в жизнь.

Многие на своем опыте знают, что такое состояние бывает временным, а бывает и достаточно стабильным. В одних местах, не только природных, но и социальных, человек себя чувствует очень комфортно, защищено, а в других - тревожно, беспокойно. Это отражает не только качество этих пространств. В этом проявляется способность самого человека настроиться на обстоятельства, понять их, от его способности гибко наладить отношения, согласовать взаимодействия. Можно сказать, что он имеет хорошие коммуникативные способности, общителен, эмоционален. Его интерактивность, включенность во взаимодействие с другими, создает хорошие перспективы. Интерактивные коммуникации, быстрый отклик на сигналы внешнего мира позволяют эффективно решать проблемы, находить ответы на возникающие вопросы. Люди, которые с легкостью понимали ситуацию и находили адекватное решение, существовали всегда, что проявляло их естественную природную способность к балансу. Они всегда стремились к риску, хотели решать сложные проблемы, испытывали себя, демонстрируя свои естественные ресурсы и творческие склонности. Однако в таком поведении нет стандартов, каждый извлекает из себя то, что получается, интуитивно схватывая условия и обстоятельства, достигая при этом успеха, но не зная, что будет в следующий раз.

В современном активном мире эта индивидуальная интерактивность становится все более важной. Если раньше можно было не спеша присмотреться к окружающей обстановке, то теперь практически нет времени на длительные размышления. Нужно успевать «схватывать на лету» не одному, а уже всем. А это значит, что теперь осознанно нужно развивать свое интерактивное коммуникативное пространство, которое человек всегда «носит с собой». Это его «подушка безопасности», которая станет препятствием для агрессии, не даст втянуться в зряшные споры, а также станет пространством установления взаимопонимания, реализации собственных творческих сил.

Но как же оказаться в этой сбалансированной форме всякий раз, когда возникает такой вызов. Кто будет настраивать человека, давать подсказки, поддерживать психологическую устойчивость? При больших проблемах это, конечно, должен делать специалист. Но и сам человек способен достаточно 
эффективно помочь себе, чтобы повысить успешность своего общения, гибкость коммуникации. Для этого он может научиться работать в интерактивном, но не внешнем, а внутреннем пространстве, защищая себя и от неожиданностей, и от крупных рисков, а также поддерживая в целом устойчивость совместной коммуникации. Такие отношения обеспечивает успешность решения человеком как своей собственной задачи, так и целей совместного взаимодействия. Гибко организовывая себя под новые условия деятельности, человек становится формирующим фактором, который способен влиять на атмосферу взаимодействия, где его намерения, ценностно-смысловая, поведенческая активность может занимать ведущее место.

Роль индивидуального состояния человека для общественно значимых результатов, как можно понять, является весьма существенной. Его активность, умение понимать мотивы участников взаимодействия, видеть знаковое пространство коммуникаций становится основой доверия и предпочтения его позиций и точек зрения, желания сонастройки и движения в том же направлении. Важно, что в этом случае человек способен не только уделять внимание своим внешним коммуникациям, но и быть внимательным к своему внутреннему состоянию, заниматься своим здоровьем, балансом организма.

По существу, работа в интерактивном поле человека - это деятельность по балансу организма, оптимизации коммуникаций как с внешними факторами, так и с внутренними. Эту помощь самому себе можно оказывать с помощью телесных - кинезиологических - упражнений, т. е. через работу с мышечным движением, позволяющем достигать необходимого баланса организма, важного психологического состояния устойчивости. Упражнения одновременно являются и легкой разминкой, и развлечением, которое интересно и взрослым, и особенно детям ${ }^{10}$.

Если исходить из того, что человек - это существо, развившее свое рефлективное, самоосознающее начало и расширившее интерактивное поле, то можно считать, что эти способности можно развивать и дальше, совершенствуя их до необходимого уровня. По существу, человек всегда должен находиться в процессе повышения своей согласованности с внешним миром, природой и людьми. При этом каждый человек создает свой личностный мир, в котором у него и воплощается его индивидуальность. Так он вписывает себя в природный континуум, являясь принципиально самостоятельным существом, способным за счет согласованности с внешним миром повышать свою устойчивость.

\footnotetext{
${ }^{10}$ Можно заметить, что современная кинезиология в России практически полностью перешла в сферу работы дефектологов, логопедов, психологов в сфере образования. См., например: Климова, 2017: Электронный ресурс.
} 
Предлагаемые кинезиологические упражнения стоит воспринимать не как настоятельные медицинские рекомендации, а как эффективную самонастройку, своеобразное «ознакомление» организма с тем, чем вы можете ему помочь (см.: Ярославцева, 2008ab). Прислушивайтесь к своим желаниям его ответам, тогда возможно будет выработать способность ответа на вызовы: при любых нагрузках человек сможет стремиться к восстановлению целостности. Для начала берите нагрузку небольшую, делайте упражнения неспешно, но, естественно, и не ожидайте результатов назавтра. Очень может быть, что послезавтра вы скажете, что собой вы точно займетесь, и это будет ваш маленький, но значительный шаг - можете поздравить себя с победой!

Для оптимизации естественно существующей в организме сложной системы балансировочных процессов можно предложить специальные упражнения. Это можно назвать кинезиологической самонастройкой, когда человек тренирует свою мышечную двигательную систему. Со временем удастся выявить, какие из упражнений оказались самыми любимыми. Это значит, что некоторые упражнения более удачно настраивают на решение собственных проблем, преодоление трудностей, а значит, соответствуют внутреннему запросу человека. Когда будет освоено столько упражнений, что можно будет выбирать, то стоит делать те, которые больше нравятся.

Кинезиологическими упражнениями можно себя и протестировать, и тренировать: выяснить, оптимально ли имеющееся состояние организма, а также избавиться от стресса, какого-либо негативного эмоционального переживания. Подобных упражнений в каждой школе, которые открыты по всей стране, разрабатывается достаточно много, в соответствии с программами коррекционной работы. Самыми распространенными становятся проблемы, актуальные для детей, для их здоровья, учебы и дальнейшего развития: родители готовы уделять внимание занятиям с детьми, и, следовательно, внимательно следят за тем, какие успехи делает ребенок. Если заглянуть на соответствующие сайты по образовательной или какой-либо иной, кинезиологии, то можно ознакомиться с большим количеством разных приемов достижения баланса организма. Самым распространенными и популярными могут быть народные игры в «ладушки», которые дети осваивают уже в младенчестве, но потом забрасывают.

Интересно отметить, что описание этих детских игр, несмотря на всю простоту движений, является достаточно сложным делом. Оказывается, что разложить на слова все взаимодействие без потерь не получается, что-то непременно ускользает. Особенно, когда нужно решить тестирующую или тренировочную задачу. В этих древних способах налаживания отношений, диктуемых непосредственно потребностью выжить, интеллект был востребо- 
ван очень слабо, а теперь для реализации потребности в самоорганизации и успешной коммуникации должен быть встроен.

\section{ЗАКЛЮЧЕНИЕ}

Как всегда, импульсивно развивающийся человек не успевает обратить внимание на свои отношения с природой в самом себе. Интеллект индивида пока свободен от этих знаний, устремлен в будущее. Человек, будучи социальным существом, интуитивно полагается на взрослых, на умную технику, на милосердие божественных сил, не замечает изменений собственных возможностей, предстоящих трансформаций в цифровой культуре и, соответственно, не знает таких слов, с помощью которых можно было бы описать нужные усилия. Для многих представителей молодого поколения новые технологии - естественный компонент их жизни, они чувствуют неограниченность своих желаний, но не имеют знаний об органичности своих глубинных потребностей и необходимости их сбережения.

У современного человека не сформирован словарь, тезаурус, настроенный на его развивающуюся телесность, мышечную активность, система понятий, посредством которой он будет не эгоистически, но диалогически обращен к себе, точнее, к природе в самом себе. На сегодняшний день это воспринимается как избыточное знание, что частично отражает реальность. Социальная практика, классическая научная парадигма не придавала человеку никакого значения, что в корне изменяет постнеклассический подход к пониманию мира.

Очень важно, что эти глубинные практики общения, ставшие игрой и упражнениями, могут приобретать расширения, являя новые эффекты при использовании современной компьютерной техники. Их можно получить при использовании интерактивных досок, панелей, планшетов, мобильных устройств. Но сегодня практически все используемое оборудование становится интерактивным и теперь уже никого не удивишь возможностью тактильного управления на электронной панели виртуальными объектами (изображениями), которые могут становиться помощниками как в самотестировании, так и в самокоррекции при выполнении упражнений (см.: Ярославцева, 2010: Электронный ресурс). Дополнительные возможности возникают при выполнении этих упражнений в объемной интерактивной среде, когда компьютер может фиксировать движения человека не на плоскости, а в пространстве. Такие технологии уже тоже развиваются и дают дополнительные возможности как для повышения эффективности тренингов баланса, так и для психологической и соматической поддержки.

Следует учитывать, что встречается оборудование, которое еще недавно относилось к разряду показываемых в кино фантастических разработок в об- 
ласти коммуникации непосредственно через функции мозга, а теперь такие предложения уже выходят на рынок и позволяют осуществлять нейрочат, управлять дистанционно с помощью интеллектуальных усилий, например, созданием сообщений. Стремительно расширяется цифровая периферия для обслуживания потребностей человека, который не может делать это непосредственно! Одновременно возникают области неизвестных проблем, которые можно отнести к сфере риска, поэтому каждому пользователю предстоит решать задачу по снятию возникающих нагрузок, развитию навыков балансировки организма.

Если учесть, что человек в современной культуре начинает переходить в новую сферу существования, в область цифровых виртуальных коммуникаций, где его тело попросту «голодает» без естественного физического движения, то система телесного восстановления баланса становится крайне необходимой. С этим напрямую связана устойчивость психологического состояния человека, позволяющая иметь перспективное мышление и осваивать проблемные области жизни, открывать новые горизонты свободы.

\section{СПИСОК ЛИТЕРАТУРЫ}

Баевский, Р. М., Берсенева, А. П. (2008) Введение в донозологическую диагностику. М. : Слово. 176 с.

Баевский, Р. М., Максимов, А. Л., Берсенева, А. П. (2001) Основы экологической валеологии человека. Магадан : МНИЦ «Арктика»; СВНЦ ДВО РАН. 266 с.

Бахтин, Ю. К. (2015) Валеология - наука о здоровье: тридцать пять лет на трудном пути становления // Молодой ученый. № 17. C. 36-42. URL: https://moluch.ru/archive/97/21893/ [архивировано в WaybackMachine] (дата обращения: 15.03.2019).

Бернштейн Николай Александрович (б/д) [Электронной ресурс] // Научная педагогическая библиотека имени К. Д. Ушинского PAO. URL: http://elib.gnpbu.ru/sections/0100/bernshtejn_n_a/ [архивировано в WaybackMachine] (дата обращения: 15.03.2019).

Бернштейн, Н. А. (1947) О построении движений. М. : Медгиз. 254 с.

Бернштейн, Н. А. (1966) Очерки по физиологии движений и физиологии активности. М. : Медицина. 349 с.

Бернштейн, Н. А. (2008) Биомеханика и физиология движений : избр. психологические труды. 3-е изд., стер. М. : Изд-во Моск. психол.-соц. ин-та ; Воронеж : Изд-во НПО «МОДЭК». 687 с.

Брехман, И. И. (1990) Валеология - наука о здоровье. 2-е изд., доп., перераб. М. : Физкультура и спорт. 208 с. 
Валитова, Н. Р. (2007) Профессиональный тезаурус как компонент профессиональной речи в формировании языковой профессиональной личности специалиста в области физической культуры и спорта // Омский научный вестник. № 5 (59). С. 122-125.

Казначеев, В. П. (1997а) Основы общей валеологии : учеб. пос. М. : Инт практической психологии ; Воронеж : МОДЭК. 48 с. (Библиотека педагогапрактика).

Казначеев, В. П. (1997b) Проблемы человековедения. М. ; Новосибирск : Исследовательский центр проблем качества подготовки специалистов. $352 \mathrm{c}$.

Казначеев, В. П., Михайлова, Л. П. (1981) Сверхслабые излучения в межклеточных взаимодействиях. Новосибирск : Наука. 145 с.

Касаткин, М. С., Ачкасов, Е. Е., Добровольский, О. Б. (2016) Основы кинезиотейпирования : учеб. пос. Изд. 2-е. М. : Спорт. 76 с.

Кинезиология (2018) [Электронной ресурс] // Википедия : свободная энциклопедия. 9 февраля. URL: https://ru.wikipedia.org/wiki/Кинезиология [архивировано в WaybackMachine] (дата обращения: 15.03.2019).

Климова, Е. (2017) Как помочь школьнику хорошо учиться и подготовиться к экзаменам? [Электронный ресурс] // SIBMEDA. 31 августа. URL: https://sibmeda.ru/articles/psikhologiya/kak-pomoch-shkolniku-khorosho-uchitsya -i-podgotovitsya-k-ekzamenam/ [архивировано в WaybackMachine] (дата обращения: 15.03.2019).

Луков, В. А., Луков, Вл. А. (2004) Тезаурусный подход в гуманитарных науках // Знание. Понимание. Умение. № 1. С. 93-100.

Луков, В. А., Луков, Вл. А. (2014) Методология тезаурусного подхода: стратегия понимания // Знание. Понимание. Умение. № 1. С. 18-35.

Маклюэн, Г. М. (2003) Понимание медиа: внешние расширения человека / пер. с англ. В. Николаева ; закл. ст. М. Вавилова. М. ; Жуковский : КАНОН-пресс-Ц ; Кучково поле. 464 с.

Матурана, У., Варела, Ф. (2001) Древо познания: биологические корни человеческого понимания / пер. с англ. Ю. А. Данилова. М. : ПрогрессТрадиция. $224 \mathrm{c.}$

Осокина, С. А. (2012) Основания лингвистической теории тезауруса: исходные основания. Барнаул : Изд-во Алт. ун-та. 251 с.

Осокина, С. А. (2015) Основания лингвистической теории тезауруса : дис. ... д-ра филол. наук. Барнаул. хvi, 451 с. URL: https://www.csu.ru/ scientific-departments/Documents/диссертация_Осокина-1.pdf [архивировано в WaybackMachine] (дата обращения: 15.03.2019). 
Поршнев, Б. Ф. (2007) О начале человеческой истории (проблемы палеопсихологии) / науч. ред. О. Т. Витте. СПб. : Алетейя. 720 с. (Сер. «Мир культуры»).

Татарникова, Л. Г. (2010) Педагогика здоровья: здоровьесберегающие образовательные технологии : науч.-метод. пос. к полипредметной программе «"Педагогическая валеология" - креативная система оздоровления информационной образовательной среды». СПб. : СПбАППО. 183 с.

Татарникова, Л. Г., Захаревич, Н. Б., Калинина, Т. О. (1997) Валеология - основы безопасности жизни ребенка : пос. к курсу валеологии «Я и мое здоровье» для шк. первой ступени. СПб. : Петроградский и Ко (PETROC). 234, [2] c.

Ярославцева, Е. И. (2008а) Коррекционные возможности кинезиологических методов с помощью интерактивных технологий на базе SMART Board // Информационные технологии в образовании : мат. XVIII Межд. конф.выставки («ИТО-2008»), г. Москва, 6-9 ноября 2008 г. М. : МИФИ. Ч. IV. С. 89-91.

Ярославцева, Е. И. (2008b) Коррекционные возможности кинезиологических методов с помощью интерактивных технологий на базе SMART Board [Электронный ресурс] // Конгресс конференций «Информационные технологии в образовании». URL: http://ito.edu.ru/2008/Moscow/III/5/III-5-7911.html [архивировано в WaybackMachine] (дата обращения: 15.03.2019).

Ярославцева, Е. И. (2010) Серия лекций «Методические решения по использованию интерактивных цифровых технологий для устойчивого развития человека» [Электронный ресурс] // UniverTV.ru. 16 февраля. URL: http://univertv.ru/video/informatika/dizajn/seriya_lekcij_metodicheskie_resheniya po ispolzovaniyu interaktivnyh_cifrovyh tehnologij_dlya_ustojc/ [архивировано в WaybackMachine] (дата обращения: 15.03.2019).

Ярославцева, Е. И. (2016) Философия инструмента: орудия и оружие войны // Философия войны и мира. К 70-летию Великой Победы : мат. Всеpoc. науч.-практ. конф. «Философия войны и мира: к 70-летию Победы в Великой Отечественной войне», г. Москва, Институт философии РАН, 28-29 апреля 2015 г. М. : Российское философское общество ; ООО «СиДиПрессАрт». 496 с. С. $440-447$.

Tgorlopeev. (2017) Нон-фикшн — что это такое в литературе? [Электронный ресурс] // SYL.ru. 20 апреля. URL: https://www.syl.ru/article/308850/ non-fikshn---chto-eto-takoe-v-literature [архивировано в WaybackMachine] (дата обращения: 15.03.2019).

Дата поступления: 17.03.20192. 


\section{REFERENCES}

Baevskii, R. M. and Berseneva, A. P. (2008) Vvedenie v donozologicheskuiu diagnostiku [Introduction in prenosological diagnostics]. Moscow : Slovo Publ. 176 p. (In Russ.).

Baevskii, R. M., Maksimov, A. L. and Berseneva, A. P. (2001) Osnovy ekologicheskoi valeologii cheloveka [Grounds of human ecological valeology]. Magadan : International Research Centre "Arktika" ; North-East Scientific Center, Far East Branch, RAS. 266 p. (In Russ.).

Bakhtin, Yu. K. (2015) Valeologiia - nauka o zdorov'e: tridtsat' piat' let na trudnom puti stanovleniia [Valeology — a science about health: Thirty five years on the difficult path of development]. Molodoi uchenyi, no. 17, pp. 36-42. [online] Available at: https://moluch.ru/archive/97/21893/ [archived in WaybackMachine] (accessed 15.03.2019). (In Russ.).

Bernshtein Nikolai Aleksandrovich (s/d) Nauchnaia pedagogicheskaia biblioteka imeni K. D. Ushinskogo RAO [online] Available at: http://elib.gnpbu.ru/ sections/0100/bernshtejn_n_a/ [archived in WaybackMachine] (accessed 15.03. 2019). (In Russ.).

Bernshtein, N. A. (1947) O postroenii dvizhenii [On building of movements]. Moscow : Medgiz Publ. 254 p. (In Russ.).

Bernshtein, N. A. (1966) Ocherki po fiziologii dvizhenii i fiziologii aktivnosti [Essays on the physiology of movements and physiology of activity]. Moscow : Meditsina Publ. 349 p. (In Russ).

Bernshtein, N. A. (2008) Biomekhanika i fiziologiia dvizhenii [Biomechanics and physiology of movements] : Selected psychological works. 3rd edn., stereotype. Moscow : Moscow Psychological and Social Institute Publ. ; Voronezh : MODEK SPA Publ. 687 p. (In Russ.).

Brekhman, I. I. (1990) Valeologiia - nauka o zdorov'e [Valeology - Science about health]. 2nd edn., enlarged and revised. Moscow : Fizkul'tura i sport Publ. 208 p. (In Russ.).

Valitova, N. R. (2007) Professional'nyi tezaurus kak komponent professional'noi rechi $\mathrm{v}$ formirovanii iazykovoi professional'noi lichnosti spetsialista v oblasti fizicheskoi kul'tury i sporta [Professional thesaurus as a component of professional speech in forming professional linguistic personality in the field of physical culture and sport]. Omskii nauchnyi vestnik, no. 5 (59), pp. 122125. (In Russ.).

Kaznacheev, V. P. (1997a) Osnovy obshchei valeologii [Foundations of general valeology] : A study guide. Moscow : Moscow Psychological and Social Institute Publ. ; Voronezh : MODEK SPA Publ. 48 p. (Series "Biblioteka pedagoga-praktika" / Library of Pedagogue-practitioner). (In Russ.). 
Kaznacheev, V. P. (1997b) Problemy chelovekovedeniia [Issues of humanology]. Moscow ; Novosibirsk : Research Centre for Problems of Quality in Specialists' Training Publ. 352 p. (In Russ.).

Kaznacheev, V. P. and Mikhailova, L. P. (1981) Sverkhslabye izlucheniia v mezhkletochnykh vzaimodeistviiakh [Superweak eradiation in cell-to-cell cooperation]. Novosibirsk : Nauka Publ. 145 p. (In Russ.).

Kasatkin, M. S., Achkasov, E. E. and Dobrovolskii, O. B. (2016) Osnovy kinezioteipirovaniia [Basics of kinesiological taping] : A study guide. 2nd edn. Moscow : Sport Publ. 76 p. (In Russ.).

Kineziologiia [Kinesiology]. (2018) Vikipediia : svobodnaia entsiklopediia [Wikipedia: The Free Encyclopedia], February 9. [online] Available at: https://ru.wikipedia.org/wiki/Кинезиология [archived in WaybackMachine] (accessed 15.03.2019). (In Russ.).

Klimova, E. (2017) Kak pomoch' shkol'niku khorosho uchit'sia i podgotovit'sia k ekzamenam? [How to help a pupil doing well and preparing for an exam?]. SIBMEDA, August 31. [online] Available at: https://sibmeda.ru/ articles/psikhologiya/kak-pomoch-shkolniku-khorosho-uchitsya-i-podgotovitsya-kekzamenam/ [archived in WaybackMachine] (accessed 15.03.2019). (In Russ.).

Lukov, V. A. and Lukov, Vl. A. (2004) Tezaurusnyi podkhod v gumanitarnykh naukakh [Thesaurus approach in the humanities]. Znanie. Ponimanie. Umenie, no. 1, pp. 93-100. (In Russ.).

Lukov, V. A. and Lukov, Vl. A. (2014) Metodologiia tezaurusnogo podkhoda: strategiia ponimaniia [The methodology of the thesaurus approach: A strategy for understanding]. Znanie. Ponimanie. Umenie, no. 1, pp. 18-35. (In Russ.).

McLuhan, H. M. (2003) Ponimanie media: vneshnie rasshireniia cheloveka [Understanding media: The extensions of man] / transl. from English by V. Nikolaev ; closing article by M. Vavilov. Moscow ; Zhukovsky : KANONpress-Ts Publ. ; Kuchkovo pole Publ. 464 p. (In Russ.).

Maturana, H. R. and Varela, F. J. (2001) Drevo poznaniia: biologicheskie korni chelovecheskogo ponimaniia [The tree of knowledge: The biological roots of human understanding] / transl. from English by Yu. A. Danilov. Moscow : Progress-Traditsiia Publ. 224 p. (In Russ.).

Osokina, S. A. (2012) Osnovaniia lingvisticheskoi teorii tezaurusa: iskhodnye osnovaniia [Foundations of the linguistic theory of thesaurus]. Barnaul : Altay University Publ. 251 p. (In Russ.).

Osokina, S. A. (2015) Osnovaniia lingvisticheskoi teorii tezaurusa [Foundations of the linguistic theory of thesaurus] : Diss. ... Doctor of Philology. Barnaul. xvi, 451 p. [online] Available at: https://www.csu.ru/scientific-departments/ 
Documents/диссертация_Осокина-1.pdf [archived in WaybackMachine] (accessed 15.03.2019). (In Russ.).

Porshnev, B. F. (2007) O nachale chelovecheskoi istorii (problemy paleopsikhologii) [On the beginning of human history (problems of paleopsychology)] / ed. by O. T. Vitte. St. Petersburg : Aleteiia Publ. 720 p. (Series "Mir kul'tury" / World of Culture). (In Russ.).

Tatarnikova, L. G. (2010) Pedagogika zdorov'ia: zdorov'esberegaiushchie obrazovatel'nye tekhnologii [Pedagogy of health: Health saving educational technologies] : A research and educational guide. St. Petersburg : St. Petersburg Academy of Postgraduate Pedagogical Education Publ. 183 p. (In Russ.).

Tatarnikova, L. G., Zakharevich, N. B. and Kalinina, T. O. (1997) Valeologiia - osnovy bezopasnosti zhizni rebenka [Valeology - Basics of child's life safety] : A course guide. St. Petersburg : Petrogradskii i Ko (PETROC) Publ. 234, [2] p. (In Russ.).

Yaroslavtseva, E. I. (2008a) Korrektsionnye vozmozhnosti kineziologicheskikh metodov s pomoshch'iu interaktivnykh tekhnologii na baze SMART Board [Correctional means of kinesiological methods with the help of interactive technologies based on SMART Board]. In: Informatsionnye tekhnologii $v$ obrazovanii [Information technologies in education] : Proceedings of the 18th International conference and exhibition ("ITE-2008"), Moscow, November 6-9, 2008. Moscow : Moscow Engineering Physics Institute Publ. Pt. IV. Pp. 89-91. (In Russ.).

Yaroslavtseva, E. I. (2008b) Korrektsionnye vozmozhnosti kineziologicheskikh metodov s pomoshch'iu interaktivnykh tekhnologii na baze SMART Board [Correctional means of kinesiological methods with the help of interactive technologies based on SMART Board]. Kongress konferentsii "Informatsionnye tekhnologii v obrazovanii". [online] Available at: http://ito. edu.ru/2008/Moscow/III/5/III-5-7911.html [archived in WaybackMachine] (accessed 15.03.2019). (In Russ.).

Yaroslavtseva, E. I. (2010) Seriia lektsii «Metodicheskie resheniia po ispol'zovaniiu interaktivnykh tsifrovykh tekhnologii dlia ustoichivogo razvitiia cheloveka» [Series of lectures "Methodical Solutions in the Application of Interactive Digital Technologies for the Human Sustainable Development"]. UniverTV.ru, February 16. [online] Available at: http://univertv.ru/video/informatika/dizajn/ seriya_lekcij_metodicheskie_resheniya_po_ispolzovaniyu_interaktivnyh_cifrovyh tehnologij_dlya_ustojc/ [archived in WaybackMachine] (accessed 15.03.2019). (In Russ.).

Yaroslavtseva, E. I. (2016) Filosofiia instrumenta: orudiia i oruzhie voiny [The philosophy of the tool: Instruments and weapons of war]. In: Filosofiia voiny i mira. K 70-letiiu Velikoi Pobedy [Philosophy of war and peace. To the 70th anni- 
versary of the Great Victory] : Proceedings of the All-Russian research-to-practice conference "Philosophy of war and peace. To the 70th anniversary of the Great Victory", Moscow, Institute of Philosophy, April 28-29, 2015. Moscow : Russian Philosophical Society ; SiDiPressArt LLC Publ. 496 p. Pp. 440-447. (In Russ.).

Tgorlopeev. (2017) Non-fikshn - chto eto takoe v literature? [Non-fiction - What is it in literature?]. SYL.ru, April 20. [online] Available at: https://www.syl.ru/article/308850/non-fikshn---chto-eto-takoe-v-literature [archived in WaybackMachine] (accessed 15.03.2019). (In Russ.).

Submission date: 17.03.2019.

Ярославцева Елена Ивановна - кандидат философских наук, доцент, старший научный сотрудник сектора философских проблем творчества Института философии РАН. Адрес: 109240, г. Москва, ул. Гончарная, д. 12, стр. 1. Тел.: +7 (495) 697-90-67. Эл. адрес: yarela@iph.ras.ru

Yaroslavtseva Elena Ivanovna, Candidate of Philosophy, Associate Professor, Senior Researcher, Department of Philosophical Problems of Creativity, Institute of Philosophy, Russian Academy of Sciences. Postal address: Bldg. 1, 12 Goncharnaya St., 109240 Moscow, Russian Federation. Tel: +7 (495) 697-90-67. E-mail: yarela@iph.ras.ru

SPIN-код РИНЦ: $\underline{\text { 6321-0584 }}$

ResearcherID: U-8911-2018

ORCID: $\underline{0000-0001-5432-9723}$

\section{Для циитирования:}

Ярославиева Е. И. Феномен саморазвития человека: кинезиология как тезаурус тела [Электронный ресурс] // Горизонты гуманитарного знания. 2019. № 2. С. 103-126. URL: http://journals.mosgu.ru/ggz/article/view/1008 (дата обращения: дд.мм.гггг). DOI: 10.17805/ggz.2019.2.8 